Article

\title{
Expert Concepts of Sustainable Service Innovation in Restaurants in Taiwan
}

\author{
Sheng-Fang Chou ${ }^{1}$, Jeou-Shyan Horng ${ }^{2}$, Chih-Hsing Liu ${ }^{3}$, Yung-Chuan Huang ${ }^{4}$ \\ and Yu-Chun Chung ${ }^{5, *}$ \\ 1 Research Center of Tourism School, Department of Hospitality Management, Ming Chuan University, \\ 5 De Ming Road, Gui Shan District, Taoyuan County 33348, Taiwan; dodo.chou@gmail.com \\ 2 Department of Food \& Beverage Management, Jinwen University of Science and Technology, No. 99, \\ Anzhong Rd., Xindian Dist., New Taipei City 23154, Taiwan; t10004@ntnu.edu.tw \\ 3 Research Center of Tourism School, Leisure \& Recreation Administration Department, \\ Ming Chuan University, 5 De Ming Road, Gui Shan District, Taoyuan County 33348, Taiwan; \\ phd20110909@gmail.com \\ 4 Research Center of Tourism School, Tourism Department, Ming Chuan University, 5 De Ming Road, \\ Gui Shan District, Taoyuan County 33348, Taiwan; ych@mail.mcu.edu.tw \\ 5 Department of Management Sciences, Tamkang University, No. 151, Yingzhuan Road, Tamsui District, \\ New Taipei City 25137, Taiwan \\ * Correspondence: dolly0105@hotmail.com; Tel.: +886-2-2621-5656 (ext. 2658)
}

Academic Editor: Ian Patterson

Received: 4 May 2016; Accepted: 7 July 2016; Published: 3 August 2016

\begin{abstract}
Sustainable service innovation is a critical attribute in restaurant management that is widely recognized by experts and restaurant owners. In this paper, we investigated ideas on sustainable service innovation in restaurants gathered from interviews with restaurant managers, government experts and scholars in Taiwan. The analytical results show that five dimensions are major indicators of sustainable service innovation in the restaurant management field. These include the following dimensions: sustainable service innovation, food service technology, organizational learning, adoption of innovation and organizational environment. We also found that these five dimensions are important and that they deeply impact restaurant performance. We discuss the characteristics of these five attributes, and talk about the theoretical and empirical implications of research findings.
\end{abstract}

Keywords: sustainable development; service innovation; restaurant; Taiwan

\section{Introduction}

Sustainable development has been highlighted worldwide as an important principle for establishing and managing organizational policies [1]. Sustainable innovations may be employed at diverse levels from the adoption of new ideas to systems in all aspects of society [2-6]. By equating sustainable thinking with innovative approaches, enterprises can acquire top-line and bottom-line benefits for their social responsibility and innovation efforts [7-10]. Besides, some researchers have started to examine the interrelationships of tourism and water use based on global, regional and business perspectives [11]. The food and beverage industry is increasingly recognizing its ability to make an environmental effort through reducing its consumption of solid waste, energy, and so on [12]. The growing interest for environmental and social considerations within the food service field is evidenced by the growth and development of green restaurants. Thus, when comparing its economic benefits to its contributions to greenhouse gas emissions, the restaurant industry is seen as one of the least sustainable economic sectors in the overall environment [1]. Food-related hospitality and tourism are integral to this process because of the way in which they simultaneously act to globalize and localize 
food consumption and create new foodways and commodity chains [13]. However, the sustainability implications of food consumption and production have so far received only little attention in the tourism literature [14,15].

The hospitality industry faces growing challenges in taking part in the trends of globalization, localization, customization and expectations of environmental concern [16-18]. The restaurant manager should keep going creative activities in the culinary process [19], also in the restaurant's atmosphere [20,21], service [22] and environment. Restaurant company attitudes can play vital roles in the success of innovation adoption and sustainable relevant practices [23]. While prior research has proven that innovation in services serves as the driving ingredient for sustainable restaurant operations [24], few studies have examined these innovations from a systematic perspective on sustainability. Despite the before-mentioned studies have shown that the key roles of sustainable service innovation in the service industry, restaurant sustainable service innovation has been neglected in relevant research. Studies about how these characteristics assist each other in restaurant sustainable service innovation is ignored theoretically and empirically. In this study, a conceptual framework has been constructed and developed that incorporates the main attributes of sustainable service innovation in restaurants from the experts' views. We adopted content analysis to measure the main attributes of restaurant sustainable service innovation. It brought about empirical examinations into academics, operations and work, and considered the valuable views of government experts.

This paper contributes to the existing literature on sustainable service innovation as follows. First, it puts forward a multidimensional perspective of restaurant sustainable service innovation and a conceptual framework for following research. Second, it develops a helpful tool to capture the perceptions of sustainable service innovation in restaurants. Third, it provides restaurant managers and practitioners in food service-related industries with a framework for structuring and developing dimensions to ensure the practices of sustainable service innovation.

This study first examines related literature on sustainable development and service innovation to construct the main framework of sustainable service innovation in restaurant management. Based on this background, the conceptual framework is then adopted as a foundation for leading an expert analysis of the dimensions of restaurant sustainable service innovation. This study concludes with a discussion of the results, research limitations and future research suggestions.

\section{Literature Review}

\subsection{Service Innovation in Restaurant Industries}

Companies regularly confront uncertainty with regard to improving environmental performance, a fact that prevents the fulfillment of innovation [25]. The theory of the diffusion of innovations [26,27] has been used to interpret and forecast behaviors regarding the adoption of innovation [28-32]. Concerning innovation, five perceived innovation characteristics (PIC) have been proposed, including relative advantage, compatibility, complexity, observability and triability. These are influential elements when considering whether to employ innovation skills [27]. The five attributes are depicted as follows: (1) Relative advantage refers to the probable advance from innovation, such as beneficial results, cost down, improved reputation, and customer satisfaction; the greater the perceived relative advantages an innovation can generate, the greater the possibility of its adoption [30,33]; (2) compatibility refers to the degree to which the potential adopters' beliefs, values and former experiences with the innovation can be expanded to a relevant level of the technical system, organizational structure or employee support [34]; (3) complexity reflects the relative embarrassment of carrying out new skills, technology or knowledge that can prevent innovation [29,30]; (4) observability reflects the degree to which the impacts of innovation can be explicitly inspected, depicted or realized by the potential adopters and is positively related to the probability of employing the innovation [34]; and (5) triability reflects the degree to which potential adopters can go through or attempt the 
innovation before actually using it. The greater the testing extent, the more likely the innovation is to be used.

Innovation adoption processes of organizations are different from those of individuals [27]. The innovation adoption decision in organizations relates to external environments, organizational scales, structures and attitudes toward the innovation. Organizational innovation is positively related to resource sufficiency, innovative belief and willingness to accept risks [35]. Other antecedents of innovation adoption have been examined in some literature, such as adopter features, social networks, environmental situations [28], government support and the level of knowledge about innovation technology [33], which have been all suggested as factors that may help to better illustrate innovation adoption behavior. Derived from the before-mentioned discussion, except for PIC, supplementary determinants still take weights. To fill the gap, several recent studies have attempted to integrate the innovation adoption theory and the theory of planned behavior (TPB) to gain more comprehension of behavioral intentions in innovation adoption [31,32,36].

The benefits of innovation in food service equipment design include: Reduction of cooking time (e.g., cooking at temperatures above water's boiling point), energy efficiency (e.g., cookware rather than the heating element is the heat source), labor saving (e.g., ultrasonic washing system), evenness of heat distribution (e.g., vertical double rotation system), superior process control (e.g., temperature control within one-tenth of a degree), modularity and flexibility (e.g., portable equipment), superior food quality (e.g., better penetration of marinade), Hazard Analysis Critical Control Point (HACCP) and good manufacturing practices (e.g., conveniently-located refrigerated units) and improved service (e.g., personalized service) [37].

\subsection{Sustainable Development of Restaurant Management}

Despite previous research of restaurants have stressed the importance of service innovation, few researchers in sustainable development and restaurant management have noticed how to survey restaurant sustainable service innovation. Sustainable service innovations indicate means of acquiring more market share by changing consumer preferences that competitors are unable to handle $[10,38,39]$. Thus, conceptualizing of innovation efforts and reducing environmental influences connect to the core of how enterprises compete in the restaurant sector. This reflects that sustainability serves as a linkage for winning business competition that revolves around innovative approaches [40]. In other words, service innovation implementation concerns the future sustainability of the restaurant industry. As a result, this study seeks to construct a helpful tool to capture experts' perceptions of sustainable service innovation in restaurants and further examine its influences on consumer satisfaction and restaurant performance.

Some recent studies have emphasized the potential for local food experiences to contribute to sustainable development, help maintain regional identities and support agricultural diversification [41-44]. Other writers have identified the market potential for "gastronomic tourism", arguing that it has strong sustainability credentials [45-48]. These findings suggest that both the production and consumption of food have a key role to play in promoting sustainable tourism development [49].

Marketing material referring to any of these factors is more likely to yield emotional responses by consumers, creating linkages among sustainability issues [50,51]. Consumers who visit restaurants seem to not only enjoy their food, but also the environment [52]. Firms attending to ecological issues are provided with an opportunity to differentiate their businesses from similar, but less ecologically-friendly firms, allowing the responsible companies to fulfill customers' desires for environmentally-friendly products or services [53]. 
Concerning the dimensions of sustainable development, the framework of green restaurant management includes: green foods (material), green environment and equipment (environment) and green management and social responsibility (people) [1]. Further, green foods (material) include: Green food procurement, green menu planning and cooking and green packaging for takeout; green environment and equipment (environment) include: Green kitchen environment, green dining environment, green cleaning and post-treatment; and finally, green management and social responsibility (people) include: Green management policy, green consumer education and green corporate social responsibility [1].

Researchers agree that involving service innovation and sustainable development in the restaurant sector is a key factor that can help to determine business values and consumer satisfaction. However, few articles have examined the relationships among operational decisions with regard to daily management, strategic determination, sustainable service innovation, and future directions from the perspective of food service experts. Thus, restaurant practitioners need to find out how to satisfy consumers and add advantage when undertaking restaurant sustainable service innovation afterward.

\section{Methods}

\subsection{Methodology}

This study adopted the qualitative method. That is, we first interviewed the experts in the restaurant industry and then used content analysis for the interview records. After the in-depth interviews, a grounded theory was used to analyze the interview data with repeated coding and reading. Sustainable service innovation was then coded into fundamental classifications with diverse descriptions [54-56]. These descriptions express the ideas and meanings derived from the interview transcripts. With regard to research reliability, we read the biographies of experts and collected relevant information, such as their provided books, documents and reports from the news. To guarantee the validity of this study, we also improved the research content with researchers' interviews and reflection notes. Those notes were observations on sustainable service innovation processes in this study, as well as economic, environmental and social implications. Thus, these systematic approaches in this study provide a theory for a specific phenomenon [54,57].

\subsection{Participants}

The data of this paper is based on expert concepts of restaurant sustainable service innovation in Taiwan and investigations into their opinions on sustainable service innovation, which have developed over the course of their specialized experience. The experts had an average of 15 years of experience in restaurant management, researching or teaching in the field of restaurant sustainable service innovation. The scholars we selected had excellent academic reputations and teaching experience in sustainable service innovation. Besides, we also consulted their publications for our selection criteria. Most of the industry experts selected had experience in assisting restaurants or hotels to carry out their sustainable service innovation. The creative restaurant managers were selected from the members of "creativity restaurant associations", which receive special awards based on exhaustive evaluation processes. This study explored experts' opinions on the importance of sustainable service innovation concepts when planning for future restaurant development, including how these concepts assist restaurant practitioners develop sustainable service innovation, how they utilize sustainable service innovation concepts in restaurant management and how they succeed in managing restaurants through sustainable service innovation views. The data collection procedure of this study is shown in Figure 1. 


\section{Stage 1 Questionnaire design}

\begin{tabular}{l} 
Literature review \\
- Hospitality management \\
- Service industrial management \\
- Sustainable development \\
- Service innovation \\
\hline
\end{tabular}

\section{Literature review}

Hospitality management

Service industrial management

Sustainable development

\section{Internal review}

Periodical meeting:

- Confirming the appropriate criteria

- Selecting the appropriate expert

- Rearrange the research schedule

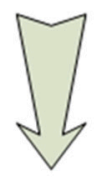

\section{Stage 2 Main criteria identification}

\section{5 experts were selected \\ - 7 industry managers \\ -5 government experts \\ - 3 academic scholars}

\section{Interview process}

- Audio-recorded

- Verbatim draft after each interview

- A total of over 200,000 words were obtained

- Content analysis

Figure 1. Sampling selection process.

\subsection{Procedure}

Before the interview process, we reviewed relevant literature regarding to hospitality management, service industrial management, sustainable development and service innovation, and identified the main characteristics of sustainable service innovation in restaurants. We integrated three phases in the interview process. First, we gave open-ended questions to experts, and made appointments to meet with them. The process was intended to ensure the experts had enough time to prepare and incorporate data to fit our demands. Then, interviews were conducted with a total of 15 experts: 7 industry experts, 5 government experts and 3 academic scholars (Table 1). We carried out two-hour, individual, and face-to-face interviews. Apart from any related follow-up questions, every expert was inquired the same questions, so that individuals' opinions could be differentiated and systematized. Third, the interview process was audio-recorded and transcribed verbatim by the interviewer. To improve quality of this study, transcriptions were created directly after the interview. A total of over 200,000 words were acquired for the 15 interviews. Besides, the analysis pays particular attention to what experts said in answer to the following questions: "What is your comprehension of sustainable service innovation in restaurants?", "What role do you think you will play in restaurant sustainable service innovation?", "How do restaurants communicate when pushing sustainable service innovation?" and "How do you train employees or students to have sustainable service innovation ability?" These questions were followed, if necessary, with further probing questions, such as: "Can you give me an instance, case or any other relevant perception regarding that?" or "What are the problems emerging in restaurant sustainable service innovation?"

The data were examined in two phases. An initial examination was based on literature reviews and results of the transcripts to determinate main classifications among the experts' opinions to sustainable service innovation in restaurants. These have been reported in $[1,58]$. The research analysis adopts the qualitative method to examine the qualitatively different ways that experts inspected sustainable service innovation; this method will be depicted later. 
Table 1. Background information of experts.

\begin{tabular}{|c|c|c|c|c|}
\hline No. & Type & Interview Date & Position & Experience (Years) \\
\hline IA & Industry & 11 September 2014 & Hotel manager & $21-30$ \\
\hline IB & Industry & 13 September 2014 & Restaurant manager & $11-20$ \\
\hline IC & Industry & 19 September 2014 & Hotel manager & $11-20$ \\
\hline ID & Industry & 25 September 2014 & Restaurant manager & $11-20$ \\
\hline IE & Industry & 2 October 2014 & Restaurant manager & Above 31 \\
\hline IF & Industry & 3 November 2014 & Hotel manager & $21-30$ \\
\hline IG & Industry & 6 November 2014 & Restaurant manager & Below 10 \\
\hline GA & Government & 12 September 2014 & Catering counselor & $11-20$ \\
\hline GB & Government & 17 September 2014 & Industry service expert & Below 10 \\
\hline GC & Government & 29 September 2014 & Tourism hospitality expert & $21-30$ \\
\hline GD & Government & 1 October 2014 & Sustainability expert & $11-20$ \\
\hline GE & Government & 20 October 2014 & Creative living counselor & $11-20$ \\
\hline SA & Scholar & 22 September 2014 & Associate professor & $11-20$ \\
\hline $\mathrm{SB}$ & Scholar & 29 September 2014 & Associate professor & $11-20$ \\
\hline $\mathrm{SC}$ & Scholar & 13 October 2014 & Professor & - \\
\hline
\end{tabular}

\section{Results}

Our critical analysis revealed expert concepts of sustainable development in restaurant service innovation. The characteristics of each concept were grouped on the basis of their main attributes: (1) Sustainable service innovation indicates green food (material)/purchases policy, using more energy-efficient cooking, green management, green environment and equipment and recommending less carbon-intensive technology; (2) food service technology relates to technology as the tool of the food industry, the reduction of cooking time and technology as a creator of the food experience; (3) organization learning relates to information sharing, the inquiry climate, learning practices and achievement mindset; (4) adoption of innovation relates to the relative advantage, compatibility, complexity, trialability and observability; and (5) organization environment relates to the encouragement of creativity, resources, autonomy or freedom and pressures. These attributes will be discussed in more detail below and supported by direct quotations from interview transcripts. All quoted names are pseudonyms coded by the interviewer.

\subsection{Sustainable Service Innovation}

Hospitality businesses influence the sustainability of their natural environment by consuming significant amounts of natural resources [1]. Their research results indicate that green restaurant management standards consist of three facets (green foods; green environment and equipment; and green management and social responsibility), nine sub-facets and 81 indicators. Food production and consumption have a range of sustainability implications, including their contribution to global greenhouse gas emissions [49]. The greening of the product innovation process has been under study by researchers and factors that affect the market performance of greener products are found to be cross-functional co-ordination between new product development experts and environmental specialists, supplier involvement, market focus and life cycle analysis [58].

\subsubsection{Green Food (Material)/Purchases Policy}

Some experts noted that green food (material)/purchases policy [1] was an important characteristic for identifying sustainable development in restaurant service innovation. The idea of green food (material)/purchases policy in restaurant sustainable service innovation must draw out consumers' delight to determine its usefulness as a sustainable service innovation. Some experts used the following short phrases to depict the relationship between green food (material)/purchases policy and sustainable service innovation appropriate to the subject of this study: 
IB: I think sustainable development can be divided into economy, culture and relationships. In the restaurant industry, it relates to purchase policy, garbage and kitchen waste recycling. ID: In terms of the purchase policy, we have continued importing from abroad, such as rainforest certified coffee.

\subsubsection{Use More Energy-Efficient Cooking}

The experts had been exposed to using more energy-efficient cooking [58] as a part of restaurant sustainable service innovation. Its attributes imply using new technology to produce food, thereby reducing labor, time and carbon emissions.

IG: There is mechanized division in the central kitchen, and the job can be more simplified in the field side. Human simplification can be more flat, and this is a super big change, because everyone resists in the beginning.

GD: The ingredients should be healthy and very safe. The restaurants should try to change the traditional way of cooking and do some energy planning.

\subsubsection{Green Management}

In order to reduce waste, pollution and costs, the internal management takes business processes and sustainable development into account [58].

GE: Such as cooking in a simple way with some sauce, so you can eat original flavor of ingredients. In this way, it will actually reduce the use of gas and electricity.

SA: In the use of technology, such as the wave oven and gas fryer, food can be cooked quickly. It also saves a lot of energy. I think these applications will replace many traditions, such as gas in Taiwan.

\subsubsection{Green Environment and Equipment}

When discussing the field of sustainable service innovation, experts said that the characteristic of green environment and equipment serves as a significant potential attribute in examining sustainable service innovation. Restaurants should use low energy appliances and prioritize health and safety in construction, such as by providing green and healthy spaces [1].

SC: The bricks are pasted on the wall and made of environmental protection material. Because it is a new modification, then you can use this concept, and consumers like this concept.

IA: There is great light and the guests have a small window at least. Everyone fears to live in a room with no windows inside, it will make them feel oppressed. So natural lighting becomes a great feature, and also closes to the concept of environmental protection.

\subsubsection{Recommending Less Carbon-Intensive Activities}

Recommending less carbon-intensive activities is an important consideration for restaurant sustainable service innovation; examples include using innovative and environmentally-friendly methods in the service process, such as mobile phone ordering [58].

IC: We do check in with a flat in the hotel. In fact, catering services will trip the hardware and guests' uses will be a little bit different.

IG: We import the ordering system. The field service personnel orders meals with a pad, then the meal information will be directly conveyed to the infield. Then, we import the QR code in a few shops. When customers order meals by QR code, this information will be recorded in the computer and conveyed. 


\subsection{Food Service Technology}

There is an increasing body of evidence referring to that consumers are becoming more ecologically conscious and willing to choose or purchase products and services that have less influence on the natural environment [59-61]. Other articles suggest that consumers not only prefer products or services that are more environmentally friendly, but also are willing to pay more as a part of being global citizens $[62,63]$. Therefore, the focus on sustainable development in restaurant service innovation has encouraged the restaurants to regulate their services and innovations to satisfy the legislation, marketing, values or expectations with regard to consumer demands concerning environmental friendliness [64].

The field of food service technology also comprises equipment and facility design, as well as the entire food service system [37]. In addition, the scope of innovative horizons should be extended beyond the traditional food service disciplines to attain other industries with higher rates of technological progress, such as medicine and space exploration. Technology in general is recognized as a contributor, creator, protector and enhancer of the consumer experience in the hospitality/tourism context [65].

\subsubsection{Technology as a Tool of the Food Industry}

Some experts asserted that technology as a tool of the food industry [65] was an important characteristic for identifying sustainable development in restaurant service innovation. The idea of technology as a tool of the food industry in restaurant sustainable service innovation must extract consumers' delight to identify the extent of sustainable service innovation. Some experts employed the following short phrases to depict the relationship between technology as a tool of the food industry and sustainable service innovation appropriate to the subject of this study:

GA: Importing ERP and controlling operations. Such as what percentage of chicken, basil and sauces, the output should be controlled.

GC: About changes in the service process, it may use electronic stuff. In the past, it could be the person's service. However, now, it is used to import POS system to order meals, or checkout with POS machines. In this way, the restaurant can simplify the human part.

\subsubsection{Reduction of Cooking Time}

Some experts addressed the reduction of cooking time as a critical characteristic in future restaurant sustainable service innovation that would affect the value put on the restaurant by consumers and consumer satisfaction. Examples include the use of technology in the preparation of dishes, making preparation faster and more secure or cooking with a distinct taste [37].

GD: There are energy-consuming kitchen stoves, extractor hood and fridge, but we did not pay much attention to these things in the past. They use the largest amount of energy when cooking. If there are other innovative ways to cook delicious and healthy food, it may save these stoves' energy and cook in energy-efficient way.

IA: We pay attention to the new appliances, such as the multifunction oven imported, which has more energy efficient and higher performance.

\subsubsection{Technology as the Creator of the Food Experience}

When discussing the respect of sustainable service innovation, the experts noted that the technology as the creator of the food experience serves as a significant potential characteristic in examining sustainable service innovation. Through technology, restauranteurs can create or provide customers with unique experiences in the process of marketing and service [65]. 
IB: About trends of the catering, such as the effect of cloud in the future, the restaurant industry does not seem to do much application. Moreover, using the QR Code and then customers can go to see some stores' information.

ID: Just go to reduce customers' waiting time, because it is what your customers are concerned about. Using the hardware or software is the most convenient and helpful. In the waiting time, just let your customers experience QR Code. Then, they can go to scan the contents, raw materials and countries of food. You provide the information communication, and customers can pass and kill the time.

\subsection{Organization Learning}

To provide a tool for assessing the basic elements of organizational learning suggested by [66] and codified by $[67,68]$ developed the Organizational Learning Profile (OLP). A more recent analysis of responses to the OLP [69] revised the loadings of some items and allowed for refinements in the naming of the following four factors: (1) Information sharing patterns; (2) inquiry climate; (3) learning practices; and (4) achievement mindset. Together, these factors describe important elements of learning in an organization.

\subsubsection{Information Sharing}

Information sharing patterns include the ways and the extent to which organizational members share information. All of the experts agreed that the restaurant industry is highly related to information sharing for sustainable service innovation; that is, members are willing to share information with each other, particularly in the catering business.

IE: I would like to say what can be done, and then we will start looking for information. There are most likely 5-6 people in every team and every team discusses. After finding what direction is relatively right, I will talk to the staff, and determine the direction and detail. IF: To some extent, we would think we have to absorb new knowledge. New knowledge comes in, and we are here to do the communication and operation. We have some new concepts, of course, and we learn many things and constantly absorb knowledge.

\subsubsection{Inquiry Climate}

The inquiry climate comprises the ways and extent to which organization members inquire, challenge and experiment to improve organizational functioning. The experts had disclosed the inquiry climate as a portion of restaurant sustainable service innovation. Members will seek out challenges, experiments and other ways to improve the operational efficiency of the restaurant.

GA: Employees are divided into groups and then start doing homework. It is essentially innovation. Encourage employees who do well and praise them in the meeting. GD: As the platform, we will go to find some foreign cases. And we play as an information provider or advisory role.

\subsubsection{Learning Practices}

The learning practices factor focuses on the types of activities in which organizational members engage to learn. When discussing the respect of sustainable service innovation, the experts said learning practices serve as a significant potential characteristic in surveying sustainable service innovation. In other words, members take the initiative to learn in order to improve the company's operations in the catering business.

SA: Suppose your proposal goes around and helps companies save money by some process, then you can get another bonus. In this way, through such a mechanism, the staff would be willing to stand and think about every deal in the process of working. I think it is reasonable to put this learning mechanism inside dining. 
SB: I think the constant attribute of successful innovation is to keep learning. Continue to accept new knowledge and challenges, and constantly keep learning new things.

\subsubsection{Achievement Mindset}

The achievement mindset factor has to do with the perspective of organization members regarding their desire to achieve in that organization. The experts had been exposed to the achievement mindset, i.e., the desire for self-realization on the part of service industry employees, as a part of restaurant sustainable service innovation.

IA: In fact, the contact with young people is very direct. The opinions of employees are usually referenced and some will be adopted. So under such circumstances, it will be very easy to get a sense of accomplishment.

\subsection{Adoption of Innovation}

Innovation behavior tracks whether an individual adopts innovations before others [27]. The researcher examined the influences of service innovation culture and changed behavior on a hotel's innovation behavior, concluding that innovation behavior raises when employees are rewarded for new ideas and encouraged to take risks [70]. Innovation management and consumer orientation have been widely recognized as key factors in enhancing the business performance of hotels [7].

\subsubsection{Relative Advantage}

All of the experts agreed that the relative advantage factor plays a large role in sustainable service innovation in the restaurant industry. The catering industry will adopt innovation and sustainable use because it perceives the comparative advantages of the program [27].

IB: After loading the grease interceptor, it spends several thousand dollars monthly for maintenance fee, such as drain cleaner. At that time, it will become our core strength, and we can say that we are environmentally friendly.

ID: Anything should go back to the basic elements of business. If you want to be able to survive, you should not be the same with someone. You have to find a way to continue to sophisticate yourself and talk to your competitor.

\subsubsection{Compatibility}

The experts had revealed compatibility as a portion of restaurant sustainable service innovation. This means that the catering industry will use innovation and sustainable solutions if they are perceived to be compatible with the existing services [27].

GA: Using the Tablet PC to order meals also involves the restaurant space. If the restaurant is very flat floor, the network system is no problem.

GC: If you import a new technology, it may streamline the labor or entire organization. In some ways, it is likely to have done so; thus, experts have been exposed to compatibility as part of restaurant sustainable service innovation. This indicates that catering industry will use innovation and sustainable solutions because of perceived compatibility with the existing services.

\subsubsection{Complexity}

When discussing the field of sustainable service innovation, the experts noted that complexity serves as a significant potential characteristic in evaluating sustainable service innovation. That is, the catering industry will use innovative and sustainable solutions if they are perceived as being easy to implement [27]. 
GD: Because this thing is sometimes advertised organic and healthy, it needs to go out looking for the supply of ingredients. It is sometimes very cumbersome and more complicated, because you have to look at the ingredients which meet your standards or not.

GE: Although you can see more details in the electronic menu, such as the material and price, it will have more information and presentation in the text. Then, it will be more complicated just like the shopping system.

\subsubsection{Trialability}

All experts agreed that the restaurant industry is extremely related to trialability for sustainable service innovation, meaning that the catering industry will adopt innovative and sustainable solutions if they can be tested first [27].

SA: Restaurants would consider the cost. I think if it is low-cost investment, restaurants might be willing to do.

ID: I think we can find one or two stores to test the experiment. However, before going to adopt this new type, we must have coordination and integration meetings to discuss the impact.

\subsubsection{Observability}

The experts had shown up observability as a portion of restaurant sustainable service innovation. Observability means that the catering industry will use innovative and sustainable solutions due to their obvious benefits [27].

GA: We received a number of cases in recent years. I will share some of these cases that we have used in the past and track. Try to convince them, and they will do it.

GB: After using the removal of fumes, it is clear to see there is no white smoke coming out of the exhaust emissions. This indicator is very clear.

\subsection{Organization Environment}

This contains all of the extrinsic motivators that have been shown to undermine intrinsic motivation, as well as lots of other factors in the environment that can serve as obstacles or as stimulants to intrinsic motivation and innovation [71]. Research in organizational settings has disclosed a number of work environment factors that can stimulate innovation, such as a sense of positive challenge in the work; work teams that are collaborative, diversely skilled and idea focused; freedom in implementing the work; supervisors who encourage the development of new ideas; top management that supports innovation through a clearly-articulated innovation-encouraging vision and appropriate recognition for creative work; mechanisms for developing new ideas; and standards of actively sharing ideas across the organization. Depending on their existing practices and current hardware/software implementations, some organizations may have to expend greater efforts to introduce IT innovations than others, and three factors seem salient: (1) The complexity of the existing IS infrastructure; (2) the need to evolve existing information systems; and (3) the unification of systems' development and management [72].

\subsubsection{Encouragement of Creativity}

All of the experts agreed that the encouragement of creativity for sustainable service innovation is highly important in the restaurant industry, meaning that executives and team members are encouraged to participate in innovation and sustainable solutions by the organization [73].

GC: Some restaurants will use the prize money to attract employees. Such as importing some technology in the process or saving in raw materials, restaurants would give the bonus to employees. 
GE: If your innovative proposal is accepted, you will be given the reward and bonuses. After the adoption, if the new innovative approach proposed is no problem, these people will get some incentive.

\subsubsection{Resources}

When discussing the facet of sustainable service innovation, the experts said that the resources serve as a significant potential characteristic in examining sustainable service innovation. This means the ability to obtain relevant resources, such as human, equipment, time, information, funding, and so on [73].

ID: For example, such as development of the product, you can get bonuses and resources. If you want to develop the product, you can use the company's raw materials.

GD: It seems to help by giving resource, such as discussions or workshops. It has become a bit like conceptual and spiritual encouragement.

\subsubsection{Autonomy or Freedom}

The experts had revealed autonomy or freedom as a portion of restaurant sustainable service innovation. This means that staff can arrange innovation and sustainable investment independently in the work program [73].

IA: This is a mutual trust. There would not be too many restrictions on employees. Under the basic service etiquette framework, employees can develop themselves.

IB: Autonomy is large. There is a big stage, plenty of room to play, and great opportunities of development.

\subsubsection{Pressures}

The experts had disclosed pressure as a portion of restaurant sustainable service innovation, i.e., the extent of the pressure felt by employees when carrying out innovative and sustainable solutions, such as time, workload, and so on [73].

GA: Innovation is determined by leaders. Innovation has two results, success and failure, and failure is usually more frequent than success. It is really a reality.

GD: The environmental pressure is large, such as the purpose of profit and consumers. The cost of the product is relatively high. And this is sustainable service, so we cannot drive down salaries of employees.

Table 2 displays the outcomes, integrating the method and focal point of each expert's conceptual classification of restaurant sustainable service innovation. There are two important ideas worth noting. First, because the classifications are inclusive, the experts who perceive more expansive levels will also include a wider range of methods to describe restaurant sustainable service innovation, whereas those who report more limited levels will not have access to the same views. Second, as we can see from the diagram, some primary qualitative differences exist between classifications defined by the variety of expert backgrounds and experience. The results have depicted the primary attribute of future restaurant sustainable service innovation and provide us with information that can be adopted in developing sustainable development in restaurant service innovation. This can help the service industry widen its viewpoint of global trends in sustainable service innovation and also their perceptions of the subject. 
Table 2. Summary of the professionals' conceptions of sustainable development in restaurant service innovation.

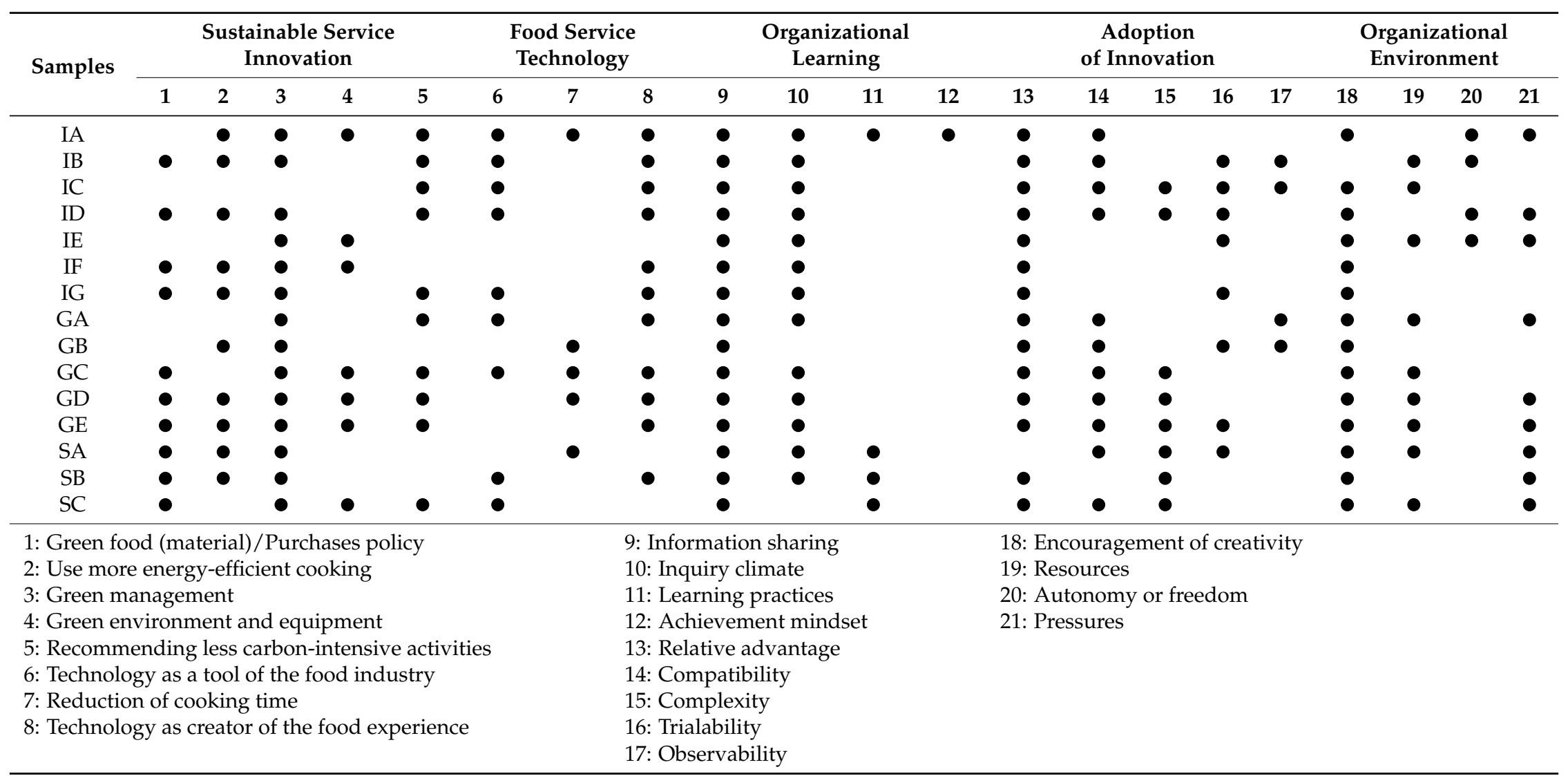


Finally, this study's findings identify the following five characteristics: Sustainable service innovation, food service technology, organizational learning, adoption of innovation and organizational environment (see Figure 2). Through the innovation adoption processes and organizational learning, and through food service technology and supportive organizational environment, these attributes can supplement one another and promote the success of sustainable service innovations in the restaurant sector.

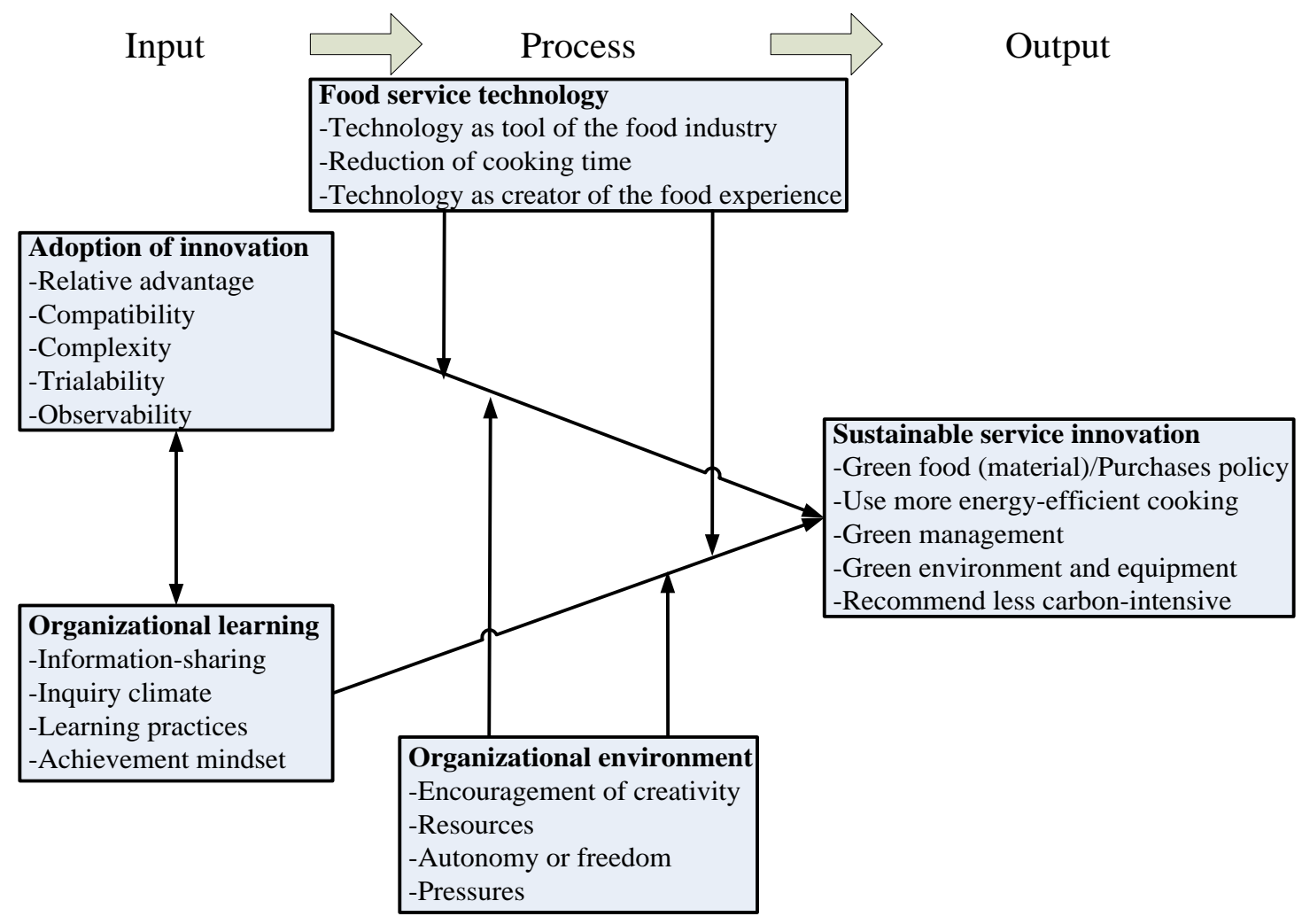

Figure 2. Conceptual framework of sustainable service innovation in restaurants.

\section{Discussion and Conclusions}

This study examined the concepts of sustainable development in restaurant service innovation among experts, adopting the qualitative method to depict their views (i.e., sustainable service innovation, food service technology, organization learning, adoption of innovation, and organization environment). The qualitative method provided logically-related categories of expert concepts of restaurant service innovation and revealed different approaches to explain the phenomenon under examination. As often as possible for each result, the conceptions of sustainable development in restaurant service innovation were identified from the narrowest and most limited to the broadest and most inclusive, both logically and empirically. The data were collected through a process of in-depth and open-ended interviews that focused on allowing each expert to fully describe his or her experience in sustainable service innovation for restaurants. The analysis of written materials depicting the experts' comprehension of the phenomenon tried to turn the broadest comprehensive depictions into the narrowest definition of the conception.

This study interviewed 15 experts with an average of 15 years of experience in restaurant management, teaching or researching sustainable service innovation. The experts who identified the least inclusive concepts are only able to adopt a single method. At the other opposite, experts who identified the most inclusive conceptions will keep their focus on the sustainable service innovation of a restaurant, but can use the entire scope of methods to support their experience. We were confident that the experts in this research comprehended the research directions. The results of this study have 
depicted actual differences and now provide us with intelligence that can be adopted to develop the conceptions of sustainable development in restaurant service innovation in the future.

Despite the conception of sustainable development appears to be a characteristic of the service industry, it seems to be rarely deliberated among experts, especially those who concentrate on restaurant service innovation. Relatively, it is held up as an attribute to aim for, and experts are told that the highest marks will be retained for trends of restaurant service innovation in the future that conform to sustainable development. Expert concepts of sustainable development in restaurant service innovation, however, as indicated earlier, provide a foundation for future discussion concentrating on this concept, along with ideas through which experts might behave sustainable development in their experience.

Besides, this study indicates that sustainability serves as a linkage for winning business competitions revolving around innovative approaches. That is, sustainable innovations bring about opportunities for enterprises to adopt solutions differently $[10,74,75]$. Through such efforts, companies can create and broaden their business landscapes in ways that mitigate social or environmental impacts, even generating more benefits or novel features [38,39]. Accordingly, this study presents a new finding that restaurants that adopt sustainable innovative processes can promote opportunities to become innovative leaders in relevant domains.

This study was designed to identify the critical attributes of sustainable service innovation for the restaurant industry. Stressing the importance of sustainability and innovation today will better allow restaurants to win the business competition tomorrow. We thus suggest that restaurant managers may use sustainable service innovations as a tool of improving their competitiveness and long-term profits. Such innovative services with fewer environmental influences in the context of corporate cultures will help generate more consumers, meet consumer expectations and enhance consumer intentions to repurchase. In addition, restaurants may promote their supply chains for more sustainable and innovative activities regarding eco-friendly issues (e.g., reducing food and material waste). These concepts of environmental thinking adopted in proactive innovative approaches not only help reduce costs, but also bring about benefits.

The findings of this study have significant implications for educational practices. In response to consumers' increasing awareness of environmental topics, incorporating environmentally-friendly ideas in restaurant management is progressing as a trend [64]. More education regarding environmentalism may need to be introduced to consumers by the government across different sectors, such as schools, enterprises and public organizations [76], with the intent to improve the awareness of environmentalism among the public so that consumers will be willing to pay for green products. Therefore, educators must be conscious that advocating sustainable service innovation notions to students will help take shape the base of future restaurant management. A related issue is teachers' adequate assessments of sustainable service innovation in their classrooms.

Discussing the nature of sustainable development is very important, that is, how it is viewed by experts with different backgrounds and how it might be believed helpful in accomplishing future requirements for environment-friendly protection. We have noticed that sustainable development in restaurant service innovation can be a useful approach to attract consumers to return [1]. Some experts, however, have also provided insightful opinions for proper paths to raise sustainable development in restaurant service innovation. A growing body of evidence finds out that customers intend to choose "green restaurants" and are willing to pay more to result less impact to the environment [12,77]. With the growing environmental consciousness, restaurant service innovation should take sustainable development into consideration in the future.

This study has some contributions in the areas that were under-researched in previous research. First, few research integrated topics of sustainable development and service innovation in restaurants, whereas almost none examined expert concepts of sustainable development in restaurants. This study fills that gap and shows evidence of the important factors that affect restaurant sustainable service innovation in Taiwan. Second, some studies have stressed the potential importance for sustainable 
service innovation in making advantageous changes and helping to retain customer loyalty and satisfaction $[1,58]$. Other researches have argued that future restaurant design should concentrate on food service technology $[38,65,78]$ because customers are willing to pay more to have less influence on the natural environment [59-61] and for "green consumption" [62,63]. These findings suggest that sustainable service innovation will play a significant role in future restaurant management $[25,49]$. This study attempted to assess the role of sustainable development in restaurant service innovation and to examine the main attributes contributing to the service industry with expert concepts. Last, the findings of this article provide a different viewpoint for comprehension the influences of restaurant sustainable service innovation on expert experience. This article proposes different attributes and sub-attributes of restaurant sustainable service innovation. These attributes can assist each other and bring about restaurant performance and consumer satisfaction.

Because this study adopts the qualitative approach to investigate the major attributes of sustainable service innovation in the restaurant industry, it is limited in that data were collected from a collectivistic society (i.e., Taiwan). Researchers have advocated for broader perspectives in cross-cultural research to better investigate the generalizability for both Western and Eastern cultures [79-82]. The second limitation refers to the fact that we carried out a content analysis based on interview results from 15 experts: 7 industry experts, 5 government experts and 3 academic scholars. Although all of these experts have an average of 15 years of experience in the restaurant industry, we arouse further research for the acquisition of more data and views from the restaurant management domain for the robustness of theoretical and structural frameworks. Besides, this study was carried out based on a self-reported survey through the collection of descriptive statements via qualitative method. Although the results of these self-reported attributes provide valuable and insightful information on sustainable ways and on relative service innovation, there is still space for improvement regarding the reliability and validity of research designs.

In short, this article's claim that few research has been conducted on restaurant sustainable service innovation has been verified. Most researches that have been published focus on either sustainable development or service innovation in restaurants, where the topic has significance in future restaurant development. Therefore, this study provides essential intelligence for future restaurant sustainable service innovation strategies and practices.

Acknowledgments: This research was financially supported through the major research plan of the Ministry of Science and Technology of Taiwan (Grant No. MOST 103-2511-S-130 -005 -MY3).

Author Contributions: The research method was proposed and conducted by Sheng-Fang Chou, Jeou-Shya Horng and Chih-Hsing Liu. The structure of the research project was discussed between Sheng-Fang Chou, Jeou-Shyan Horng, Chih-Hsing Liu, Yung-Chuan Huang, and Yu-Chun Chung. The paper was written by Yu-Chun Chung.

Conflicts of Interest: The authors declare no conflict of interest.

\section{References}

1. Wang, Y.F.; Chen, S.P.; Lee, Y.C.; Tsai, C.T. Developing green management standards for restaurants: An application of green supply chain management. Int. J. Hosp. Manag. 2013, 34, 263-273. [CrossRef]

2. Hekkert, M.P.; Negro, S.O. Functions of innovation systems as a framework to understand sustainable technological change: Empirical evidence for earlier claims. Technol. Forecast. Soc. Chang. 2009, 76, 584-594. [CrossRef]

3. Schot, J.; Geels, F.W. Strategic niche management and sustainable innovation journeys: Theory, findings, research agenda, and policy. Technol. Anal. Strateg. Manag. 2008, 20, 537-554. [CrossRef]

4. Seyfang, G.; Smith, A. Grassroots innovations for sustainable development: Towards a new research and policy agenda. Environ. Polit. 2007, 16, 584-603. [CrossRef]

5. Aldebert, B.; Dang, R.J.; Longhi, C. Innovation in the tourism industry: The case of tourism@. Tour. Manag. 2011, 32, 1204-1213. [CrossRef] 
6. Williams, A.M.; Shaw, G. Internationalization and innovation in tourism. Ann. Tour. Res. 2011, 38, 27-51. [CrossRef]

7. Grissemann, U.; Plank, A.; Brunner-Sperdin, A. Enhancing business performance of hotels: The role of innovation and customer orientation. Int. J. Hosp. Manag. 2013, 33, 347-356. [CrossRef]

8. Nidumolu, R.; Prahalad, C.K.; Rangaswami, M.R. Why sustainability is now the key driver of innovation. Harv. Bus. Rev. 2009, 87, 56-65.

9. Johnson, K.; Hays, C.; Center, H.; Daley, C. Building capacity and sustainable prevention innovations: A sustainability planning model. Eval. Progr. Plan. 2004, 27, 135-149. [CrossRef]

10. Sbai, S. Sustainable culinary systems: Local foods, innovation, tourism and hospitality. J. Sustain. Tour. 2014, 22, 1122-1124. [CrossRef]

11. Gössling, S.; Hall, C.M.; Scott, D. Tourism and Water; Channel View: Bristol, UK, 2015.

12. Hu, M.L.; Horng, J.S.; Teng, C.C.; Chiou, W.B.; Yen, C.D. Fueling green dining intention: The self-completion theory perspective. Asia Pac. J. Tour. Res. 2014, 19, 793-808. [CrossRef]

13. Hall, C.M.; Gössling, S. Sustainable Culinary Systems: Local Foods, Innovation, and Tourism E Hospitality; Routledge: London, UK, 2013.

14. Hunter, $\mathrm{C}$. Aspects of the sustainable tourism debate from a natural resources perspective. In Sustainable Tourism: A Global Perspective; Harris, R., Griffin, T., Williams, P., Eds.; Butterworth-Heinemann: Oxford, UK, 2002; pp. 3-23.

15. Telfer, D.J.; Wall, G. Strengthening backward economic linkages: Local food purchasing by three Indonesian hotels. Tour. Geogr. 2000, 2, 421-447. [CrossRef]

16. Hu, M.L.; Horng, J.S.; Sun, Y.H. Hospitality teams: Knowledge sharing and service innovation performance. Tour. Manag. 2009, 30, 41-50.

17. López-Mosquera, N.; Sánchez, M. Emotional and satisfaction benefits to visitors as explanatory factors in the monetary valuation of environmental goods. An application to periurban green spaces. Land Use Pol. 2011, 28, 151-166. [CrossRef]

18. Mayer, F.S.; Frantz, C.M. The connectedness to nature scale: A measure of individuals' feeling in community with nature. J. Environ. Psychol. 2004, 24, 503-515. [CrossRef]

19. Horng, J.S.; Hu, M.L. The creative culinary process: Constructing and extending a four-component model. Creat. Res. J. 2009, 21, 376-383. [CrossRef]

20. Jang, S.; Namkung, Y. Perceived quality, emotions, and behavioral intentions: Application of an extended Mehrabian-Russell model to restaurants. J. Bus. Res. 2009, 62, 451-460. [CrossRef]

21. Kim, Y.; Lee, S.; Boo, S. Impact of brand recognition and brand reputation on firm performance: U.S.-based multinational restaurant companies' perspective. Int. J. Hosp. Manag. 2009, 28, 620-630.

22. Kincaid, C.; Baloglu, S.; Mao, Z.; Busser, J. What really brings them back? The impact of tangible quality on affect and intention for casual dining restaurant patrons. Int. J. Contemp. Hosp. Manag. 2010, 22, 209-220. [CrossRef]

23. Wu, K.J.; Liao, C.J.; Tseng, M.L.; Chou, P.J. Understanding innovation for sustainable business management capabilities and competencies under uncertainty. Sustainability 2015, 7, 13726-13760. [CrossRef]

24. Lin, C.S.; Chang, R.Y.; Dang, V. An integrated model to explain how corporate social responsibility affects corporate financial performance. Sustainability 2015, 7, 8292-8311. [CrossRef]

25. Chou, C.J.; Chen, K.S.; Wang, Y.Y. Green practices in the restaurant industry from an innovation adoption perspective: Evidence from Taiwan. Int. J. Hosp. Manag. 2012, 31, 703-711. [CrossRef]

26. Rogers, E.M. Diffusion of Innovations; The Free Press: New York, NY, USA, 1962.

27. Rogers, E.M. Diffusion of Innovations, 4th ed.; The Free Press: New York, NY, USA, 1995.

28. Frambach, R.T.; Schillewaert, N. Organizational innovation adoption: A multilevel framework of determinants and opportunities for future research. J. Bus. Res. 2002, 55, 163-176. [CrossRef]

29. Gopalakrishnan, S.; Damanpour, F. Patterns of generation and adoption of innovation in organizations: Contingency models of innovation attributes. J. Eng. Technol. Manag. 1994, 11, 95-116. [CrossRef]

30. Lin, J.Y.C.; Wang, E.S.T.; Kao, L.L.Y.; Cheng, J.M.S. A study of perceived recognition affecting the adoption of innovation with respect of the online game in Taiwan. Cyberpsychol. Behav. 2007, 10, 813-815. [CrossRef] [PubMed]

31. Lim, W.M. Alternative models framing UK independent hoteliers' adoption of technology. Int. J. Contemp. Hosp. Manag. 2009, 21, 610-618. [CrossRef] 
32. Marcati, A.; Guildo, G.; Peluso, A.M. The role of SME entrepreneurs' innovativeness and personality in the adoption of innovations. Res. Policy 2008, 37, 1570-1590. [CrossRef]

33. Jeon, B.N.; Han, K.S.; Lee, M.J. Determining factors for the adoption of E-business: The case of SMEs in Korea. Appl. Econ. 2006, 38, 1905-1916. [CrossRef]

34. Le, Y.; Hollenhorst, S.; Harris, C.; McLaughlin, W.; Shook, W. Environmental management: A study of Vietnamese hotels. Ann. Tour. Res. 2006, 33, 547-567. [CrossRef]

35. Wan, D.; Ong, C.H.; Lee, F. Determinants of firm innovation in Singapore. Technovation 2005, 25, $261-268$. [CrossRef]

36. Wu, I.L.; Chen, E.L. An extension of trust and TAM model with TPB in the initial adoption of on-line tax: An empirical study. J. Hum. Comput. Stud. 2005, 62, 784-808. [CrossRef]

37. Rodgers, S. Innovation in food service technology and its strategic role. Int. J. Hosp. Manag. 2007, 26, 899-912. [CrossRef]

38. Bramwell, B.; Lane, B. Towards innovation in sustainable tourism research? J. Sustain. Tour. 2012, $20,1-7$. [CrossRef]

39. Hjalager, A.M. Innovation patterns in sustainable tourism-An analytical typology. Tour. Manag. 1997, 18, 35-41. [CrossRef]

40. Horng, J.S.; Wang, C.J.; Liu, C.H.; Chou, S.F.; Tsai, C.Y. The role of sustainable service innovation in crafting the vision of the hospitality industry. Sustainability 2016, 8, 223. [CrossRef]

41. Clark, G.; Chabrel, M. Measuring integrated rural tourism. Tour. Geogr. 2007, 9, 371-386. [CrossRef]

42. Everett, S.; Aitchison, C. The role of food tourism in sustaining regional identity: A case study of Cornwall, South West England. J. Sustain. Tour. 2008, 16, 150-167. [CrossRef]

43. Knowd, I. Tourism as a mechanism for farm survival. J. Sustain. Tour. 2006, 14, 24-42. [CrossRef]

44. Sims, R. Food, place and authenticity: Local food and the sustainable tourism experience. J. Sustain. Tour. 2009, 17, 321-336. [CrossRef]

45. Hall, C.M. Wine, Food and Tourism Marketing; Haworth: Binghamton, NY, USA, 2003.

46. Hall, C.M.; Sharples, L.; Mitchell, R.; Macionis, N.; Cambourne, B. Food Tourism around the World: Development, Management and Markets; Butterworth-Heinemann: Oxford, UK, 2003.

47. Hjalanger, A.M.; Richards, G. Tourism and Gastronomy; Routledge: Abingdon, UK, 2002.

48. Du Rand, G.E.; Heath, E. Towards a framework for food tourism as an element of destination marketing. Curr. Issues Tour. 2006, 9, 206-234.

49. Gössling, S.; Garrod, B.; Aall, C.; Hille, J.; Peeters, P. Food management in tourism: Reducing tourism's carbon 'foodprint'. Tour. Manag. 2011, 32, 534-543. [CrossRef]

50. Harper, G.C.; Makatouni, A. Consumer perception of organic food production and farm animal welfare. Br. Food J. 2002, 104, 287-299. [CrossRef]

51. Ilbery, B.; Kneafsey, M. Producer constructions of quality in regional speciality food production: A case study from South West England. J. Rural Stud. 2000, 16, 217-230. [CrossRef]

52. Heung, V.C.S. American theme restaurants: A study of consumer's perceptions of the important attributes in restaurant selection. Asia Pac. J. Tour. Res. 2002, 7, 19-28. [CrossRef]

53. Ham, S.; Han, H. Role of Perceived Fit with Hotels' Green Practices in the Formation of Customer Loyalty: Impact of Environmental Concerns. Asia Pac. J. Tour. Res. 2013, 18, 731-748. [CrossRef]

54. Corbin, J.; Strauss, A. Grounded theory research-Procedures, canons and evaluative criteria. Qual. Soziol. 1990, 19, 418-427. [CrossRef]

55. Rennie, D.L.; Phillips, J.R.; Quartaro, G.K. Grounded theory-A promising approach to conceptualization in psychology. Can. Psychol. 1988, 29, 139-150. [CrossRef]

56. Martin, P.Y.; Turner, B.A. Grounded theory and organizational research. J. Appl. Behav. Sci. 1986, 22, $141-157$. [CrossRef]

57. Hsieh, H.F.; Shannon, S.E. Three approaches to qualitative content analysis. Qual. Health Res. 2005, 15, 1277-1288. [CrossRef] [PubMed]

58. Pujari, D. Eco-innovation and new product development: Understanding the influences on market performance. Technovation 2006, 26, 76-85. [CrossRef]

59. Han, H.; Hsu, L.T.; Sheu, C. Application of the theory of planned behavior to green hotel choice: Testing the effect of environmental friendly activities. Tour. Manag. 2010, 31, 325-334. [CrossRef] 
60. Mohr, L.A.; Webb, D.J. The effect of corporate social responsibility and price on consumer responses. J. Consum. Aff. 2005, 39, 121-147. [CrossRef]

61. Tilikidou, I. The effects of knowledge and attitudes upon Greek's pro-environmental purchasing behavior. Corp. Soc. Responsib. Environ. Manag. 2007, 14, 121-134. [CrossRef]

62. Laroche, M.; Bergeron, J.; Barbaro-Forleo, G. Targeting consumers who are willing to pay more for environmentally friendly products. J. Consum. Mark. 2001, 18, 503-520. [CrossRef]

63. Coddington, W.; Florain, P. Environmental Marketing: Positive Strategies for Reaching the Green Consumer; McGraw-Hill: New York, NY, USA, 1993.

64. Jeong, E.H.; Jang, S.C. Effects of Restaurant Green practices: Which practices are important and effective? Caesars Hosp. Res. 2010, 13, 1-23.

65. Rodgers, S. The state of technological sophistication and the need for new specialised tertiary degrees in food services. Int. J. Hosp. Manag. 2009, 28, 71-77. [CrossRef]

66. Levitt, B.; March, J.G. Organizational learning. Annu. Rev. Sociol. 1988, 14, 319-340. [CrossRef]

67. Huber, G.P. Organizational learning: The contributing processes and the literatures. Organ. Sci. 1991, 2, 81-115. [CrossRef]

68. Pace, R.W.; Regan, L.; Miller, P.; Dunn, L. Natural growth goals and short-term training: A boomerang effect. Int. J. Train. Dev. 1998, 2, 128-140. [CrossRef]

69. Dorai, R.; McMurray, A.; Pace, R.W. A Study of the Organizational Learning Profile; Swinburne University of Technology: Melbourne, Australia, 2001.

70. Chen, W.J. Innovation in hotel services: Culture and personality. Int. J. Hosp. Manag. 2011, 30, 64-72. [CrossRef]

71. Amabile, T.M. Componential Theory of Creativity; Harvard Business School Working Paper, No. 12-096; Harvard Business School: Boston, MA, USA, 2012.

72. Hackney, R.; Xu, H.; Ranchhod, A. Evaluating Web Services: Towards a framework for emergent contexts. Eur. J. Oper. Res. 2006, 173, 1161-1174. [CrossRef]

73. Amabile, T.M. Creativity and Innovation in Organizations; Harvard Business School: Boston, MA, USA, 1996.

74. Luis Nicolau, J.; Jesus Santa-Maria, M. The effect of innovation on hotel market value. Int. J. Hosp. Manag. 2013, 32, 71-79. [CrossRef]

75. Nieves, J.; Quintana, A.; Osorio, J. Knowledge-based resources and innovation in the hotel industry. Int. J. Hosp. Manag. 2014, 38, 65-73. [CrossRef]

76. Tsai, Y.H.; Wu, C.T.; Wang, T.M. Attitude towards green hotel by hoteliers and travel agency managers in Taiwan. Asia Pac. J. Tour. Res. 2014, 19, 1091-1109. [CrossRef]

77. Hu, H.H.; Parsa, H.G.; Self, J. The dynamics of green restaurant patronage. Cornell Hosp. Q. 2010, 51, 344-362. [CrossRef]

78. Rodgers, S. Food service research: An integrated approach. Int. J. Hosp. Manag. 2011, 30, 477-483. [CrossRef]

79. Meng, H.; Huang, P.; Hou, N.; Fan, J. Social self-efficacy predicts Chinese college students' first-year transition: A four-wave longitudinal investigation. J. Career Assess. 2015, 23, 410-426. [CrossRef]

80. Lin, Y.J.; Flores, L.Y. Job search self-efficacy of East Asian international graduate students. J. Career Dev. 2013, 40, 186-202. [CrossRef]

81. Ma, Z.W.; Zeng, W.N.; Ye, K.Y. Gender differences in Chinese adolescents' subjective well-being: The mediating role of self-efficacy. Psychol. Rep. 2015, 116, 311-321. [CrossRef] [PubMed]

82. Ye, Y. Role of career decision-making self-efficacy and risk of career options on career decision-making of Chinese graduates. Psychol. Rep. 2014, 114, 625-634. [CrossRef] [PubMed]

(c) 2016 by the authors; licensee MDPI, Basel, Switzerland. This article is an open access article distributed under the terms and conditions of the Creative Commons Attribution (CC-BY) license (http://creativecommons.org/licenses/by/4.0/). 